\title{
PARTISIPASI MASYARAKAT DALAM PROGRAM PENGEMBANGAN KAWASAN AGROPOLITAN DESA BEJIHARJO KABUPATEN GUNUNG KIDUL
}

\author{
Oleh: \\ Galuh Citraningrum, Nurhadi, Bambang Syaefulhadi \\ Jurusan Pendidikan Geografi FISE-UNY
}

\begin{abstract}
$\underline{\text { Abstrak }}$
Pengelolaan Tujuan penelitian ini yaitu mengetahui pelaksanaan program pengembangan kawasan agropolitan dan mengetahui besarnya partisipasi masyarakat di Desa Bejiharjo dalam pelaksanaan program pengembangan kawasan agropolitan.

Penelitian ini dilakukan secara deskriptif kuantitatif. Variabel penelitian yaitu pelaksanaan program pengembangan kawasan agropolitan dan partisipasi masyarakat. Populasi penelitian adalah seluruh kepala keluarga (KK) di Desa Bejiharjo yang berjumlah 4.229 KK. Sampel dalam penelitian ini berjumlah $255 \mathrm{KK}$ ditentukan dengan formula Isaac dan Michael dengan tingkat kesalahan 10\%. Teknik pengambilan sampel menggunakan teknik cluster random sampling (area sampling), teknik proportional sampling, teknik systematical random sampling. Teknik pengumpulan data dilakukan dengan cara wawancara, observasi, dan dokumentasi. Teknik pengolahan dan analisis data menggunakan analisis skoring yang disajikan melalui tabel serta metode checklist untuk penentuan klasifikasi strata jenis agropolitan.

Hasil penelitian menunjukkan bahwa pelaksanaan program pembangunan kawasan agropolitan di Desa Bejiharjo dalam kurun waktu tahun 2005-2009 belum seluruhnya tercapai secara optimal. Partisipasi masyarakat dalam program pengembangan kawasan agropolitan mempunyai skor 2117,88 dan berada pada tingkat partisipasi sedang.
\end{abstract}

Kata Kunci: Pengelolaan kawasan, agropolitan, partisipasi masyarakat

\section{Pendahuluan}

Pembangunan adalah usaha untuk memajukan kehidupan masyarakat dan warganya (Arief Budiman, 1995:1). Pembangunan sering diartikan sebagai kemajuan yang dicapai oleh sebuah masyarakat di bidang ekonomi. Pada wilayah perdesaan, pembangunan pada hakekatnya berupaya meningkatkan pendapatan masyarakat melalui pengembangan sektor-sektor potensial desa. 
Partisipasi Masyarakat dalam Program Pengembangan Kawasan Agropoplitan Desa Bejiharjo

Kabupaten Gunung Kidul

Kawasan perdesaan berperan penting sebagai penjamin ketersedian pangan untuk mencapai keamanan pangan nasional, penyedia bahan mentah bagi industri, sekaligus penyedia lapangan kerja, pemberi sumbangan pendapatan nasional. Secara konseptual pembangunan wilayah perdesaan ditujukan pada usaha percepatan pembangunan di segala bidang dalam rangka meningkatkan kualitas hidup masyarakat yang maju, mandiri, dan sejahtera (Sukorini, 2004:1).

Perdesaan adalah suatu daerah yang ditempati oleh sejumlah penduduk sebagai suatu kesatuan mayarakat termasuk di dalamnya kesatuan masyarakat hukum yang mempunyai organisasi terendah langsung di bawah camat dan berhak menyelenggarakan rumah tangganya sendiri dalam ikatan Negara Kesatuan Republik Indonesia (Undang-undang Nomor 5 tahun 1979). Ciri-ciri umum dari daerah perdesaan menurut Saleh Amiruddin dalam Hadi Sabari Yunus (1994:22-23) adalah sebagai berikut: 1) Sebagian besar mata pencaharian penduduk adalah petani. 2) Kepadatan penduduk agak rendah. 3) Kebutuhan penduduk sederhana. 4) Tempat kerja berada di sekitar. 5) Cara kehidupan sosial gotong royong. 6) Komunikasi dilakukan dengan jalan kaki dan alat angkut sederhana. 7) Built up-areas sporadis.

Gunung Kidul merupakan salah satu Kabupaten di Provinsi D.I Yogyakarta yang identik dengan daerah perdesaan. Dari 18 kecamatan di Gunung Kidul, 139 dari 144 kelurahan/desa tergolong kawasan perdesaan. (http://www.mudrajad.com). Desa yang jauh dengan keramaian dan hiburan, umumnya masih tertinggal dalam berbagai jenis infrastruktur. Sesuai dengan karakteristik wilayah Kabupaten Gunungkidul, peran sektor pertanian (tanaman pangan, hortikultura, perkebunan, peternakan, perikanan dan kehutanan) masih merupakan sektor andalan. Hal ini tercermin dari mata pencaharian masyarakat Gunungkidul yang 69\% bertumpu pada sektor pertanian serta dilihat dari kontribusi sektor pertanian terhadap Produk Domestik Regional Bruto (PDRB) paling tinggi bila dibandingkan dengan sektor-sektor lainnya yaitu 31\% (www.gunungkidulkab.com).

Sejalan dengan visi Kabupaten Gunung Kidul yaitu "Terwujudnya Kabupaten Gunung Kidul sebagai daerah pengembangan pertanian, Industri Kecil dan Menengah, Pariwisata yang berbudaya, dengan didukung pemerintahan yang baik dan bersih, sumber daya manusia yang berkualitas menuju kemandirian dan peningkatan taraf hidup masyarakat", maka sektor pertanian dalam arti luas mendapat prioritas pengembangan. Wilayah-wilayah yang didominasi oleh sektor pertanian tersebut umumnya terletak di daerah perdesaan (rural). Salah satu cara untuk percepatan pengembangan perdesaan adalah dengan pengembangan kawasan agropolitan.

Pada tahun 2004 BAPPEDA kabupaten Gunung Kidul telah melakukan suatu kajian pengembangan kawasan agropolitan untuk memilih lokasi area pengembangan. Berdasarkan kriteria-kriteria dan teknik pemilihan lokasi 
tersebut diperoleh prioritas pengembangan kawasan agropolitan di Kecamatan Karangmojo dan sebagai pusatnya adalah Desa Bejiharjo. Hinterland Kawasan Agropolitan Bejiharjo adalah desa-desa di tujuh kecamatan sekitarnya yakni Kecamatan Karangmojo, Kecamatan Wonosari, Kecamatan Nglipar, Kecamatan Ngawen, Kecamatan Semin, Kecamatan Semanu, dan Kecamatan Ponjong. Penetapan lokasi telah disahkan Bupati Gunung Kidul dengan Surat Keputusan Nomor 42/KPTS/2005 Tanggal 2 Mei tentang Lokasi Pengembangan Kawasan Agropolitan di Kabupaten Gunung Kidul.

Program pengembangan kawasan agropolitan Bejiharjo merupakan program yang diberikan pemerintah guna mendukung pembangunan perdesaan. Program ini telah berjalan selama kurang lebih 4 tahun mulai tahun 2005 sampai sekarang. Dalam pelaksanaannya, program pembangunan memerlukan peran dari seluruh stakeholder baik dari pemerintah maupun masyarakat. Adanya kendala-kendala dalam pelaksanaan program pengembangan kawasan agropolitan Bejiharjo meyebabkan semua program pembangunan dapat dicapai secara optimal.

Program agropolitan merupakan program bottom-up yang memerlukan partisipasi aktif dari masyarakat. Masyarakat tidak hanya berperan sebagai objek pembangunan, melainkan juga sebagai subjek pembangunan. Partisipasi masyarakat dalam program pembangunan agropolitan ini meliputi aspek perencanaan, pelaksanaan, tindak lanjut, dan monitoring/evaluasi pada setiap kegiatan program yang telah ditetapkan.

\section{Partisipasi Masyarakat Perdesaan}

Loekman Sutrisno (1995:221-222) mengemukakan bahwa Partisipasi rakyat dalam pembangunan sebagai dukungan rakyat terhadap rencana atau proyek pembangunan yang dirancang dan ditentukan tujuannya oleh perencana. Ukuran tinggi rendahnya partisipasi masyarakat diukur dari kemauan rakyat ikut menanggung biaya pembangunan, baik berupa uang ataupun tenaga dalam melaksanakan proyek pembangunan pemerintah. Ditambahkan Loekman Sutrisno bahwa partisipasi rakyat dalam pembangunan merupakan kerjasama yang erat antara perencana dan rakyat dalam merencanakan, melaksanakan, melestarikan, dan mengembangkan hasil pembangunan yang telah dicapai. Ukurannya yaitu pada ada tidaknya hak rakyat untuk ikut menentukan arah dan tujuan proyek yang akan dibangun di wilayah mereka dan kemauan rakyat untuk secara sendiri melestarikan dan mengembangkan hasil proyek itu. Britha Mikkelsen (1999:65), mengungkapkan bahwa partisipasi adalah alat dalam memajukan ideologi atau tujuan-tujuan pembangunan yang normatif seperti keadilan sosial, persamaan, dan demokrasi. Implikasinya, partisipasi menyangkut pula strategi manajemen, melalui mana negara mencoba untuk memobilisasi sumber-sumbernya" 
Mubyarto dan Sartono Kartodirdjo (1988:37) mengemukakan bahwa partisipasi masyarakat dalam pembangunan perdesaan harus diartikan secara lebih luas yaitu kesediaan untuk membantu berhasilnya setiap program sesuai kemampuan setiap orang tanpa berarti mengorbankan kepentingan sendiri.

Berdasarkan definisi-definisi tersebut dapat ditarik kesimpulan bahwa partisipasi masyarakat adalah keterlibatan masyarakat dalam suatu kegiatan pembangunan mulai dari perencanaan, pelaksanaan dan pemanfaatan, tindak lanjut, serta evaluasi atau pengembangan untuk mencapai tujuan bersama. Partisipasi masyarakat merupakan alat informasi terhadap sikap masyarakat terhadap proyek pembangunan. Partisipasi masyarakat akan menentukan keberhasilan pembangunan. Semakin tinggi nilai partisipasi masyarakat maka keberhasilan pembangunan diharapkan juga akan semakin tinggi. Dengan keterlibatan masyarakat dalam pembangunan, maka pembangunan akan lebih diarahkan untuk perbaikan hidup dirasakan sepenuhnya oleh masyarakat.

\section{Konsepsi Kawasan Agropolitan}

Konsep pengembangan agropolitan menurut John Friedmann dan Mc. Douglass (Anonim, 1986: 164) memberikan spesifikasi ukuran agropolitan distrik sebagai berikut:

"In purely formal terms, agropolitan districts were defined as rural areas with effective population densities of at least 200 per $\mathrm{km}$. A town between 10.000-25.000 in habitants would normally be found within the district and the district boundaries would be defined by commuting radius of between 5 and $10 \mathrm{~km}$ (or approximately one hour's travel time bicycle). Such dimensions would yield an overall size of population ranging from 50.000 to 150.000 of whom a majority would be initially engaged in farming."

Nasutin dalam Moehar Daniel (2002:172-173) mengemukakan konsep agropolitan merupakan pengembangan kota setara kabupaten yang mengembangkan desa berdasarkan komoditi unggulan dan penunjangnya. Pusat pertumbuhan dibangun agroindustri untuk membentuk suatu usaha koperasi, perusahaan kecil dan menengah serta memungkinkan petani untuk bekerja pada waktu paro. Menurut Soenarno (2003), konsepsi kawasan agropolitan ini juga dicirikan dengan kawasan pertanian yang tumbuh dan berkembang karena berjalannya sistem dan usaha agribisnis di pusat agropolitan yang diharapkan dapat melayani dan mendorong kegiatan-kegiatan pembangunan pertanian (agribisnis) di wilayah sekitarnya. Konsep ini sejalan dengan konsep agropolitan di Desa Bejiharjo dan daerah hinterlandnya. Desa Bejiharo sebagai pusat pertumbuhan kawasan agropolitan Kabupaten Gunung Kidul diharapkan dapat menumbuhkan pusat-pusat pertumbuhan pembangunan baru di kawasan hinterlandnya. 
Kawasan Agropolitan merupakan kota pertanian yang tumbuh dan berkembang karena berjalannya sistem dan usaha agribisnis serta mampu melayani, mendorong, menarik, menghela kegiatan pengembangan pertanian (agribisnis) di wilayah sekitarnya. Program pengembangan kawasan sentra produksi pangan (agropolitan) adalah pembangunan ekonomi berbasis pertanian yang dilaksanakan dengan jalan mensinergikan berbagai potensi yang ada, yang utuh dan menyeluruh, yang berdaya saing, berbasis kerakyatan, berkelanjutan dan terdesentralisasi, yang digerakkan oleh masyarakat dan difasilitasi oleh pemerintah (BAPPEDA Gunung Kidul, 2004:7). Berdasarkan pengertian kawasan agropolitan di atas dapat ditarik kesimpulan bahwa agropolitan adalah kota pertanian berbasis potensi yang ada yang tumbuh dan berkembang dengan sistem usaha agribisnis yang mendukung pula kegiatan pengembangan pertanian di wilayah sekitarnya. Kawasan agropolitan didukung dengan sarana prasarana yang ada seperti di kota.

Kawasan agropolitan yang sudah berkembang memiliki ciri-ciri: kegiatan agribisnis, ada keterkaitan kota dengan desa, sebagian besar pendapatan masyarakat dari kegiatan agribisnis, dan kehidupannnya mirip dengan suasana kota (Anonim, 2002). Suatu wilayah dapat dikembangkan menjadi suatu kawasan agropolitan bila dapat memenuhi persyaratan memiliki sumber daya lahan, sarana dan prasarana agribisnis, sarana dan prasarana umum, sarana dan prasarana kesejahteraan masyarakat, serta konservasi alam dan kelestarian lingkungan hidup (BAPPEDA Gunung Kidul, 2004:8-10).

Sumber daya lahan dengan agroklimat yang sesuai untuk mengembangkan komoditi pertanian khususnya pangan dan memiliki komoditi unggulan yang terdiversifikasi. Disamping itu tersedia fasilitas mulai pembibitan sampai penjualannya. Memiliki prasarana dan infrastrukur yang memadai untuk mendukung pengembangan sistem dan usaha agribisnis, seperti pasar, lembaga keuangan, kelembagaan petani (kelompok, koperasi, asosiasi), Balai Penyuluhan Pertanian (BPP), dan Percobaan/pengkajian teknologi agribisnis untuk mengembangkan teknologi tepat guna yang cocok untuk kawasan agropolitan setempat, serta Jaringan jalan yang memadai.

Persyaratan lain suatu kawasan dijadikan daerah agropolitan yaitu memiliki sarana dan prasarana umum yang memadai, seperti transportasi, jaringan listrik, telekomunikasi, dan air bersih. Selanjutnya memiliki sarana dan prasarana kesejahteraan sosial/masyarakat seperti kesehatan, pendidikan, kesenian, rekreasi, perpustakaan, dan swalayan serta Koservasi alam dan kelestarian lingkungan hidup bagi kelestarian sumber daya alam, kelestarian sosial budaya maupun ekosistem secara keseluruhan.

Pengembangan kawasan agropolitan di Desa Bejiharjo merupakan upaya pembangunan kawasan perdesaan di dalam satu wilayah kabupaten. Pusat pengembangan meliputi satu wilayah desa dan sebagai pusat pertumbuhan adalah Desa Bejiharjo dengan didukung fasilitas pertanian di 
sekitarnya. Daerah yang merupakan daerah hinterland adalah tujuh kecamatan di sekitar Desa Bejiharjo yakni Kecamatan Karangmojo, Kecamatan Ponjong, Kecamatan Semin, Kecamatan Wonosari, Kecamatan Nglipar, Kecamatan Ngawen, dan Kecamatan Semanu.

\section{Metode Penelitian}

Penelitian ini menggunakan desain survei yang dideskriptisikan secara kuantitatif melalui analisis skoring. Variabel dalam penelitian ini yaitu partisipasi masyarakat dalam program pengembangan kawasan Agropolitan. Populasi penelitian ini yaitu seluruh Kepala Keluarga (KK) di Desa Bejiharjo sejumlah $4.229 \mathrm{KK}$. Penentuan jumlah sampel menggunakan rumus Isaac dan Michael dengan tingkat kesalahan 10\%, yaitu:

$$
\mathrm{s}=\frac{\lambda^{2} \cdot N \cdot P \cdot Q}{\mathrm{~d}^{2}(\mathrm{~N}-1)+\lambda^{2} \cdot P \cdot Q}
$$

$\lambda^{2}$ dengan $\mathrm{dk}=1$, taraf kesalahan bisa $1 \%, 5 \%$, dan $10 \%$.

$P=Q=0,5 ; d=0,05: s=j u m l a h$ sampel.

Berdasarkan rumus tersebut diperoleh sampel sebanyak $255 \mathrm{KK}$. Teknik pengambilan sampel melalui Cluster Random Sampling (Area Sampling) digunakan untuk menentukan sampel dusun dan diperoleh yaitu Dusun Grogol IV, Dusun gelaran I, Dusun Sokoliman I, Dusun Gelaran II, dan Dusun Banyubening I. Teknik proportional sampling digunakan untuk untuk menentukan jumlah responden. Teknik Systematical Random Sampling digunakan untuk menentukan sampel responden dan diperoleh sampel bernomor kelipatan lima.

Teknik pengumpulan data yaitu dengan metode wawancara, obervasi, dan dokumentasi. Teknik pengolahan dan analisis data dalam menentukan besarnya partisipasi masyarakat yakni memberi skor dengan nilai 0-100 dari 43 butir pertanyaan. Setelah besar skor diperoleh, kemudian diklasifikasikan ke dalam kelas besar partisipasi yaitu rendah, sedang, dan tinggi dengan menggunakan rumus:

$$
P=\frac{X n-X i}{K}
$$

$\mathrm{P}=$ Panjang Kelas Interval

$\mathrm{Xi}=$ Data Terkecil (skor terendah)

$\mathrm{X} n=$ Data Terbesar (skor tertinggi)

$\mathrm{K}=$ Banyak Kelas

(Sugiyono, 2007:31) 
Maka dapat ditentukan kelompok tingkat partisipasi masyarakat yaitu: Tingkat partisipasi rendah yaitu 0-1433, tingkat partisipasi sedang yaitu 14342867, dan tingkat partisipasi tinggi yaitu 2868-4300.

Analisis data yang digunakan adalah analisis data statistik deskriptif dan ditampeilkan dalam bentuk tabel-tabel frekuensi.

\section{Hasil Penelitian dan Pembahasan}

Penilaian terhadap paritispasi Masyarakat dalam program pengembangan kawasan agropolitan di Desa Bejiharjo diperoleh dari penilaian aspek perencanan, pelaksanaan, tindak lanjut, serta kegiatan evaluasi, maka tingkat partisipasi dapat diketahui dengan menjumlahkan nilai rata-rata semua kategori yang berasal dari aspek tersebut.

\section{Aspek Perencanaan}

Partisipasi masyarakat dalam aspek perencanaan yakni melalui musyawarah tahunan program pengembangan Kawasan Agropolitan.

Tabel 1 . Partisipasi Masyarakat Dalam Aspek Perencanaan

\begin{tabular}{|c|c|c|c|c|c|}
\hline No & Aspek Penilaian & Skor & $\mathrm{F}$ & $\%$ & $\begin{array}{l}\text { Skor } \\
\text { Akhir }\end{array}$ \\
\hline \multirow[t]{5}{*}{1.} & Musyawarah tahunan & & & & \\
\hline & a. ya & 100 & 255 & 100 & 25500 \\
\hline & b. tidak & 0 & 0 & 0 & 0 \\
\hline & Jumlah & & 255 & 100 & 25500 \\
\hline & Rata-rata & & & & 100 \\
\hline \multirow[t]{7}{*}{2.} & Kehadiran musyawarah tahunan & & & & \\
\hline & a. selalu & 100 & 60 & 23,52 & 6000 \\
\hline & b. sering & 50 & 37 & 14,52 & 1850 \\
\hline & c. kadang-kadang & 25 & 13 & 6,00 & 325 \\
\hline & d. tidak pernah & 0 & 145 & 56,86 & 0 \\
\hline & Jumlah & & 255 & 100 & 8175 \\
\hline & Rata-rata & & & & 32,06 \\
\hline \multirow[t]{7}{*}{3.} & Usul untuk merencanakan program & & & & \\
\hline & a. selalu & 100 & 24 & 9,41 & 2400 \\
\hline & b. sering & 50 & 32 & 12,55 & 1600 \\
\hline & c. kadang-kadang & 25 & 39 & 15,29 & 975 \\
\hline & d. tidak pernah & 0 & 160 & 62,75 & 0 \\
\hline & Jumlah & & 255 & 100 & 4975 \\
\hline & Rata-rata & & & & 19,51 \\
\hline \multirow[t]{5}{*}{4.} & Mengetahui hasil musyawarah tahunan & & & & \\
\hline & a. ya & 100 & 215 & 84,31 & 21500 \\
\hline & b. tidak & 0 & 40 & 15,69 & 0 \\
\hline & Jumlah & & 255 & 100 & 21500 \\
\hline & Rata-rata & & & & 84,65 \\
\hline
\end{tabular}

Sumber : Data primer, 2009 
Partisipasi Masyarakat dalam Program Pengembangan Kawasan Agropoplitan Desa Bejiharjo

Kabupaten Gunung Kidul

Dalam perencanaan tersebut, partisipasi masyarakat diukur berdasarkan pengetahuan keberadaan tentang musyawarah tahunan program pengembangan Kawasan Agropolitan, kehadiran dalam musyawarah tersebut, dan pengetahuan masyarakat tentang hasil musyawarah tahunan. Data selengkapnya pada tabel 1.

Berdasarkan tabel 1 dapat disimpulkan bahwa seluruh responden menjawab adanya musyawarah tahunan tentang perencanaan program pengembangan kawasan agropolitan di desa ini. Dengan demikian, seluruh responden mengetahui tentang adanya musyawarah tahunan.

2. Aspek Pelaksanaan dan Pemanfaatan

Partisipasi masyarakat dalam pelaksanaan dan pemanfaatan dilakukan melalui program pemberdayaan masyarakat, kelembagaan masyarakat (petani pada khususnya), dan sarana dan prasarana.

a. Pemberdayaan Masyarakat

Usaha pemberdayaan masyarakat terhadap kegiatan pengembangan kawasan agropolitan di Desa Bejiharjo dilakukan untuk peningkatan produktivitas usaha tani serta dengan dukungan terhadap produk komoditas unggulan yang dibudidayakan disajikan tabel 2.

Tabel 2. Partisipasi Masyarakat Dalam Penyuluhan

\begin{tabular}{|c|c|c|c|c|c|}
\hline No & Aspek Penilaian & Skor & $\mathrm{F}$ & $\%$ & Skor Akhir \\
\hline \multirow[t]{5}{*}{1.} & $\begin{array}{l}\text { Pengetahuan tentang ada tidaknya } \\
\text { penyuluhan }\end{array}$ & & & & \\
\hline & a. ya & 100 & 130 & 50,98 & 13000 \\
\hline & b. tidak & 0 & 125 & 49,02 & 0 \\
\hline & Jumlah & & 255 & 100 & 13000 \\
\hline & Rata-rata & & & & 50,98 \\
\hline \multirow[t]{7}{*}{2.} & Kehadiran dalam penyuluhan & & & & \\
\hline & a. selalu & 100 & 33 & 12,94 & 3300 \\
\hline & b. sering & 50 & 41 & 16,08 & 2050 \\
\hline & c. kadang-kadang & 25 & 90 & 35,29 & 2250 \\
\hline & d. tidak pernah & 0 & 91 & 35,69 & 0 \\
\hline & Jumlah & & 255 & 100 & 7600 \\
\hline & Rata-rata & & & & 29,80 \\
\hline \multirow[t]{5}{*}{3.} & $\begin{array}{l}\text { Keaktifan bertanya/mengemukakan } \\
\text { pendapat dalam kegiatan penyuluhan }\end{array}$ & & & & \\
\hline & a. ya & 100 & 102 & 40,00 & 10200 \\
\hline & b. tidak & 0 & 153 & 60,00 & 0 \\
\hline & Jumlah & & 255 & 100 & 10200 \\
\hline & Rata-rata & & & & 40,00 \\
\hline \multirow[t]{5}{*}{4.} & Komunikasi informal dengan penyuluh & & & & \\
\hline & a. ya & 100 & 128 & 50,20 & 12800 \\
\hline & b. tidak & 0 & 127 & 49,80 & 0 \\
\hline & Jumlah & & 255 & 100 & 12800 \\
\hline & Rata-rata & & & & 49,80 \\
\hline
\end{tabular}

Sumber : Data primer, 2009 
Berdasarkan hasil wawancara terhadap responden dapat diperoleh informasi bahwa kegiatan penyuluhan secara formal dilakukan lebih dari tiga kali setiap tahun. Selain dari penyuluh, informasi tentang usaha tani dapat diperoleh dari membaca buku, atau petani lainnya.

Penilaian masyarakat terhadap produk komoditas unggulan yang dikembangkan terdiri dari diversifikasi, lebih dari satu jenis, satu jenis komoditas, dan yang tidak mengembangkan produk komoditas usaha tani. Data selengkapnya pada tabel 3.

Tabel 3. Partisipasi Masyarakat Terhadap Produk Komoditas Unggulan

\begin{tabular}{|c|l|r|r|r|r|}
\hline No & \multicolumn{1}{|c|}{ Aspek Penilaian } & Skor & \multicolumn{1}{|c|}{ F } & \multicolumn{1}{c|}{ Skor Akhir } \\
\hline \multirow{4}{*}{1} & Jenis komoditas yang dikembangkan & & & & \\
\cline { 2 - 6 } & a. diversifikasi & 100 & 255 & 100 & 25400 \\
\cline { 2 - 6 } & b. lebih dari satu jenis & 50 & 0 & 0 & 0 \\
\cline { 2 - 6 } & c. satu jenis komoditas & 25 & 0 & 0 & 0 \\
\cline { 2 - 6 } & d. tidak mengembangkan & & 0 & 0 & 0 \\
\cline { 2 - 6 } & Jumlah & & & & 100 \\
\cline { 2 - 6 } & Rata-rata & & & 100 \\
\hline
\end{tabular}

Sumber: Data Primer, 2009

Berdasarkan tabel 3 dapat diperoleh kesimpulan bahwa jenis komoditas yang dikembangkan oleh seluruh responden adalah diversifikasi. Produk yang dikembangkan berupa usaha tani tanaman pangan dan hortikultura, perikanan, peternakan, perkebunan, dan kehutanan.

b. Kelembagaan Masyarakat

Kelembagaan masyarakat dalam program agropolitan di desa ini yakni kelembagaan petani. Kelembagaan tersebut terdiri dari kelompok tani, gabungan kelompok tani, dan kelembagaan koperasi. Semua responden dalam penelitian ini mengetahui keberadaan kelompok tani di desa ini. Dari 255 responden, yang merupakan anggota kelompok tani sebanyak 105 orang (41,17\%), sedangkan yang tidak merupakan anggota dari kelompok tani berjumlah 150 orang (58,83\%). Tahun keanggotaan responden paling banyak pada tahun 2005 yakni berjumlah 62 orang $(24,31 \%)$. Sedangkan tahun keanggotaan yang lain jumlahnya bervariasi. Tahun 2006 sebanyak 12 orang (4,71\%), tahun 2007 sebanyak 16 orang (6,27\%), dan tahun 2008 sebanyak 15 orang (5,88\%). Adanya pertemuan kelompok tani diketahui oleh responden sebanyak 105 orang $(41,17 \%)$, sedangkan yang tidak mengetahui adanya pertemuan kelompok 150 orang (58,83\%). Kehadiran kelompok dalam pertemuan jumlahnya bervariasi. Responden yang selalu mengikuti berjumlah 32 orang (12,55\%). Sering hadir dalam pertemuan berjumlah 35 orang (13,72\%). Kadang-kadang hadir 38 orang $(14,90 \%)$, tidak pernah hadir berjumlah 150 orang (58,83\%). 
Penilaian pada kategori ini yakni partisipasi pada keberadaan gabungan kelompok tani, pelaksanaan pertemuan gabungan kelompok tani, dan kehadiran anggota. Dari 255 responden, yang mengetahui keberadaan gabungan kelompok tani sebanyak 105 orang $(41,17 \%)$, sedangkan yang tidak mengetahui sebanyak 150 orang (58,83\%). Jumlah tersebut sama halnya dengan responden yang mengetahui adanya pertemuan yakni 105 orang (41,17\%), sedangkan yang tidak mengetahui adanya pertemuan berjumlah 150 orang (58,83\%). Semua responden mengetahui keberadaan koperasi yakni 100\%. Responden yang ikut serta dalam anggota koperasi yakni 136 orang $(53,33 \%)$, sedangkan yang tidak ikut serta dalam anggota berjumlah 119 orang (46,67\%).

c. Sarana dan Prasarana

Penilaian partisipasi terhadap sarana dan prasarana agropolitan yakni sumbangan masyarakat terhadap sarana dan prasarana serta pemanfaatan sarana dan prasarana.

Tabel 4. Partisipasi Masyarakat Terhadap Sumbangan Pembangunan Sarana dan Prasarana Agropolitan

\begin{tabular}{|c|l|r|r|r|r|}
\hline No & \multicolumn{1}{|c|}{ Aspek Penilaian } & Skor & \multicolumn{1}{|c|}{ F } & $\%$ & Skor Akhir \\
\hline \multirow{3}{*}{1.} & Sumbangan pembangunan & & & & \\
\cline { 2 - 6 } & a. ya & 100 & 255 & 100 & 25500 \\
\cline { 2 - 6 } & b. tidak & 0 & 0 & 0 & 0 \\
\cline { 2 - 6 } & Jumlah & & 255 & 100 & 25500 \\
\cline { 2 - 6 } & Rata-rata & & & & 100 \\
\hline
\end{tabular}

Sumber: Data Primer, 2009

Berdasarkan data pada tabel 4 di atas diperoleh kesimpulan bahwa seluruh responden memberikan sumbangan terhadap pembangunan sarana dan prasarana agropolitan. Berdasarkan informasi yang diperoleh dari wawancara terhadap responden, sumbangan masyarakat terdiri dari uang/dana, tenaga, tanah/lahan, dan batu. Pembangunan sarana dan prasarana tidak hanya dilakukan oleh pemerintah, tetapi juga justru swadaya masyarakat tinggi. Pembangunan dilakukan secara gotong royong. Masyarakat dengan rela memberikan bantuannya baik berupa tenaga, tanah/lahan, dan batu tanpa minta ganti rugi dari pemerintah.

Aspek penilaian partisipasi terhadap pemanfaatan sarana prasarana agropolitan disini yang dimaksud adalah pergudangan, jalan usaha tani, irigasi, air bersih, kandang sapi, pasar ikan, dan kolam ikan air tawar. Air bersih dan jalan usaha tani merupakan sarana agropolitan yang selalu digunakan petani. Sedangkan sarana yang tidak pernah digunakan adalah pasar ikan, restoran ikan terapung, dan kandang sapi. Responden yang mengatakan sering menggunakan kolam ikan air tawar berjumlah 10 
orang (1,97\%), kadang-kadang 5 orang $(3,94 \%)$, dan yang tidak pernah menggunakan 239 orang (94,09\%).

3. Aspek Tindak Lanjut (pemeliharaan sarana prasarana dan konservasi)

Aspek tindak lanjut dari partisipasi masyarakat ditunjukkan oleh partisipasi dalam konservasi air dan hutan, dan pemeliharaan sarana prasarana.

a. Partisipasi Dalam Konservasi Sumber Air dan Hutan

Konservasi disini yakni perlindungan terhadap konservasi sumbersumber air dan hutan (reboisasi). Penilaian konservasi terdiri dari pengetahuan tentang keberadaan kegiatan konservasi, kegiatan konservasi, dan pelaksanaan konservasi. Responden yang mengetahui tentang kegiatan konservasi berjumlah 50 orang (19,61\%), sedangkan yang tidak mengetahui kegiatan konservasi 204 orang (80,39\%). Kegiatan konservasi yang dilakukan gotong royong dilakukan sejumlah 35 orang $(13,73 \%)$ responden. Sedangkan responden yang mengatakan kegiatan konservasi dilakukan oleh pengelola agropolitan berjumlah 15 orang (5,88\%). Kegiatan konservasi dilakukan tidak tentu. Responden yang sering mengikuti kegiatan konservasi hanya kadang-kadang yakni berjumlah 35 orang $(13,73 \%)$, sedangkan yang lainnya berjumlah 219 orang $(85,89 \%)$ tidak pernah mengikuti.

b. Pemeliharaan Sarana dan Prasarana

Penilaian partisipasi masyarakat terhadap pemeliharaan sarana dan prasarana agropolitan terdiri dari sistem pemeliharaan sarana prasarana, pelaksanan dalam kegiatan pemeliharaan, kegiatan gotongroyong, serta sumbangan dalam pemeliharaan. Sistem pemeliharaan sarana dan prasarana agropolitan dilakukan secara bersama-sama dan gotong-royong seluruh lapisan baik dari pemerintah maupun masyarakat itu sendiri. Pelaksanaan pemeliharaan sarana prasarana pada masing-masing wilayah (komplek/dusun) dilakukan berbeda-beda. Responden yang mengatakan kegiatan tersebut secara rutin (terjadwal) sebanyak 127 orang $(49,80 \%)$. Sedangkan responden yang mengatakan kegiatan dilakukan tidak tentu sebanyak 128 orang $(50,20 \%)$.

Informasi yang diperoleh dari wawancara terhadap responden dalam kegiatan pemeliharaan (pembersihan) yang mengatakan rutin yakni pada hari-hari tertentu tiap minggu sesuai masing-masing wilayah. Sedangkan beberapa responden yang mengatakan tidak tentu karena disesuaikan pada waktu senggang, atau kadang kegiatan tersebut dilakukan serta merta saja secara mendadak jika kegiatan tersebut perlu dilakukan.

Keikutsertaan masyarakat dalam kegiatan gotong-royong beragam. Responden yang mengatakan selalu mengikuti kegiatan gotong-royong adalah paling banyak yakni sejumlah 190 orang (74,51\%). Sedangkan 
responden yang sering mengikuti kegiatan gotong-royong berjumlah 26 orang $(10,20 \%)$. Responden yang hanya kadang-kadang berjumlah 36 orang $(14,11 \%)$. Dan yang tidak pernah mengikuti kegiatan gotong-royong berjumlah dua orang $(1,18 \%)$. Semua responden mengatakan turut serta memberikan sumbangan terhadap pembangunan sarana dan prasarana agropolitan. Data selengkapnya pada tabel 30.

Berdasarkan informasi yang diperoleh dari wawancara terhadap responden sumbangan berupa uang yakni dipungut pada setiap kegiatan seperti pertemuan RT dan sebagainya. Simpanan KAS atau uang iuran tersebut kemudian digunakan untuk konsumsi (snack) dan minuman pada saat kegiatan gotong royong dilakukan.

4. Aspek Evaluasi/monitoring

Penilaian partisipasi masyarakat dalam aspek evaluasi/monitoring program terdiri dari keberadaan musyawarah evaluasi program, kehadiran dalam evaluasi, keikutsertaan dalam memberikan masukan terhadap kegiatan evaluasi, dan mengetahui atau tidaknya hasil evaluasi.

Tabel 5. Partisipasi Terhadap Kegiatan Evaluasi

\begin{tabular}{|c|c|c|c|c|c|}
\hline No & Aspek Penilaian & Skor & $\mathrm{F}$ & $\%$ & Skor Akhir \\
\hline \multirow[t]{5}{*}{1.} & Musyawarah evaluasi program & & & & \\
\hline & a. ya & 100 & 255 & 100 & 25500 \\
\hline & b. tidak & 0 & 0 & 0 & 0 \\
\hline & Jumlah & & 255 & 100 & 25500 \\
\hline & Rata-rata & & & & 100 \\
\hline \multirow[t]{7}{*}{2.} & Kehadiran dalam evaluasi program & & & & \\
\hline & a. selalu & 100 & 60 & 23,53 & 6000 \\
\hline & b. sering & 50 & 37 & 14,51 & 1850 \\
\hline & c. kadang-kadang & 25 & 12 & 4,71 & 300 \\
\hline & d. tidak pernah & 0 & 146 & 57,25 & 0 \\
\hline & Jumlah & & 255 & 100 & 8150 \\
\hline & Rata-rata & & & & 31,96 \\
\hline \multirow[t]{7}{*}{3.} & Memberi masukan untuk evaluasi & & & & \\
\hline & a. selalu & 100 & 24 & 9,41 & 2400 \\
\hline & b. sering & 50 & 32 & 12,55 & 1600 \\
\hline & c. kadang-kadang & 25 & 39 & 15,29 & 975 \\
\hline & d. tidak pernah & 0 & 160 & 62,75 & 0 \\
\hline & Jumlah & & 255 & 100 & 4975 \\
\hline & Rata-rata & & & & 19,51 \\
\hline \multirow[t]{5}{*}{4.} & Mengetahui hasil evaluasi & & & & \\
\hline & a. ya & 100 & 255 & 100 & 25500 \\
\hline & b. tidak & 0 & 0 & 0 & 0 \\
\hline & Jumlah & & 255 & 100 & 25500 \\
\hline & Rata-rata & & & & 100 \\
\hline
\end{tabular}

Sumber: Data Primer, 2009 
Berdasarkan tabel 5 di atas, semua responden mengetahui keberadaan musyawarah evaluasi program. Kehadiran dalam kegiatan musyawarah bervasiasi. Responden yang mengatakan yang selalu hadir dalam kegiatan tersebut berjumlah 60 orang (23,53\%). Yang mengatakan sering mengikuti 37 orang (14,51\%). Kadang-kadang mengikuti evaluasi 39 orang (15,29\%). Sedangkan responden yang tidak pernah mengikuti evaluasi berjumlah 146 orang $(57,25 \%)$.

\section{Kesimpulan}

Tingkat partisipasi masyarakat dalam program pengembangan kawasan agropolitan di Desa Bejiharjo yaitu berada pada tingkat sedang dengan jumlah skor 2117,88 . Swadaya dan perhatian masyarakat tinggi, namun pengetahuan masyarakat terhadap program agropolitan sendiri oleh pihak terkait masih kurang sehingga respon masyarakat terhadap program masih transparan.. Agar partisipasi masyarakat, baik dari perencanaan, pelaksanaan, tindak lanjut, dan evaluasi dalam program pengembangan kawasan agropolitan dapat lebih tinggi lagi maka diperlukan sosialisai pendidikan untuk meningkatkan sumber daya masyarakat sehingga keberhasilan pembangunan dapat terwujud dan hasil pembangunan dapat dirasakan masyarakat sepenuhnya

\section{Daftar Pustaka}

Anonim. (2002). Pedoman Umum Pengembangan Kawasan Agropolitan. Jakarta: Departemen Pertanian RI.

Arief Budiman. (1995). Teori Pembangunan Dunia Ketiga. Jakarta: PT. Gramedia Pustaka Utama.

BAPPEDA. (2008). Pengembangan Kawasan Agropolitan Kabupaten Gunung Kidul dan Hinterlandnya. Tidak diterbitkan.

BAPPEDA. (2007). Rencana Strategis Badan Pemerintahan Daerah Kabupaten Gunung Kidul (http://www.bappeda.gunungkidulkab.go.id diambil tanggal 20 Januari 2009).

BAPPEDA. (2004). Rencana Pengembangan Kawasan Agropolitan Kabupaten Gunung Kidul. Tidak diterbitkan.

Kantor Lurah Desa Bejiharjo. (2007). Rekapitulasi Hasil Pendataan Keluarga Tingkat Desa/Kelurahan. Tidak diterbitkan

Loekman Soetrisno. (1995). Menuju Masyarakat Partisipatoris. Yogyakarta: Kanisius. 
Moehar Daniel. (2002). Pengantar Ekonomi Pertanian. Jakarta: PT. Bumi Aksara.

Mubyarto dan Sartono Kartodirjo. (1988). Pembangunan Perdesaan di Indonesia. Yogyakarta: Liberty.

Pemerintah Daerah Kabupaten Gunung Kidul. Potensi Kabupaten Gunung Kidul (www.gunungkidulkab.com diambil tanggal 16 Januari 2008).

Soenarno. (2003). Pengembangan Kawasan Agropolitan Dalam Rangka Pengembangan Wilayah. Makalah Seminar Nasional Agroindustri dan Pengembangan Wilayah. Departemen Permukiman dan Prasarana Wilayah R. I.

Sugiyono. (2007). Statistika Untuk Penelitian. Bandung: Penerbit Alfabeto. 